\title{
Transient expression of wild-type and mutant glucocerebrosidases in hybrid vaccinia expression system
}

\author{
Kateřina Hodaňová ${ }^{1}$, Zora Mělková ${ }^{2,3}$, Mia Horowitz ${ }^{4}$, and Martin Hřebíček ${ }^{*, 1}$ \\ ${ }^{1}$ Center for Integrated Genomics and Institute of Inherited Metabolic Disorders, First Faculty of Medicine, Charles \\ University, Ke Karlovu 2, Praha 2, 128 08, Czech Republic; ${ }^{2}$ Department of Pathological Physiology, First Faculty of \\ Medicine, Charles University, U nemocnice 5, Praha 2, 128 53, Czech Republic; ${ }^{3}$ Department of Immunology and \\ Microbiology, First Faculty of Medicine, Charles University, Studnickova 7, Praha 2, 128 00, Czech Republic; \\ ${ }^{4}$ Department of Cell Research and Immunology, Tel Aviv University, Ramat Aviv 69978, Israel
}

Gaucher disease, the most prevalent lysosomal storage disease, is characterised by a significant phenotypic variation caused by more than 150 mutations. In order to verify pathogenicity of mutations found in the Czech Gaucher population, the vaccinia expression system was used. The wild-type human $\beta$ glucocerebrosidase cDNA and cDNAs carrying the mutations 72delC, 1326insT, 1263del55, S196P, N370S, L444P, G202E, D409H, T369M, L444P+V460V, and D409H+T369M were expressed in Gaucher fibroblast cell line (L444P/S107L), BSC40, and HeLa G cells. The enzymatic activity and immunological reactivity were analysed. Only $\beta$-glucocerebrosidase-deficient fibroblasts were suitable for expression using plasmid transfection. The expressed $\beta$-glucosidase activity of mutant glucocerebrosidases was in good correlation with the presumed severity of the mutations.

European Journal of Human Genetics (2003) 11, 369-374. doi:10.1038/sj.ejhg.5200974

Keywords: Gaucher disease; mutations; hybrid vaccinia expression system

\section{Introduction}

Gaucher disease is a sphingolipid storage disorder caused by a hereditary deficiency of lysosomal hydrolase $\beta$ glucocerebrosidase. Glucocerebrosidase cleaves the $\beta$ glycosidic bond between the ceramide and glucose moieties of glucosylceramide and its deficiency leads to storage of glucosylceramide, preferentially in the cells of monocyte-macrophage origin. Patients usually present with splenomegaly, hepatomegaly, thrombocytopenia, and often with bone disease. Three clinical types of the disease are recognised on the basis of the progression of the disease and CNS involvement: type 1 (non-neuronopathic), type 2 (acute neuronopathic) and type 3 (subacute neurono-

*Correspondence: Dr Martin Hřebíček, Institute of Inherited Metabolic Diseases, Div. B, Ke Karlovu 2, Praha 2, 128 08, Czech Republic.

Tel.: +420 22496 7701; Fax: +420 22491 9392;

E-mail: martin.hrebicek@lf1.cuni.cz

Received 30 August 2002; revised 27 January 2003; accepted 29 January 2003 pathic). Clinical manifestation in the most prevalent type 1 is heterogeneous. ${ }^{1}$

More than 150 glucocerebrosidase gene mutations were described in Gaucher patients (http://archive.uwcm.ac.uk/ uwcm/mg/search/119262.html). In non-Jewish populations common mutations account for about $70 \%$ of mutant alleles, the rest of the alleles are occupied by rare or private mutations. From the prevalent mutations only three cell lines were derived from homozygous patients (N370S, L444P, and D409H), thus enabling the study of the properties of the appropriate mutant protein. Therefore, in vitro expression of mutant protein is necessary for the study of other mutant glucocerebrosidases. Most importantly, in vitro expression of the mutant protein and its activity is necessary to distinguish between missense mutation and a neutral polymorphism.

Since glucocerebrosidase is a glycoprotein and glycosylation is necessary for its catalytic activity, expression in eukaryotic systems is necessary for the functional studies of 
mutant glucocerebrosidase. Glucocerebrosidase has been previously expressed in COS cells, however, the activity of the expressed wild-type glucocerebrosidase was only two or three times higher than the endogenous $\beta$-glucosidase activity of the cell line. ${ }^{2}$

Higher levels of expression were achieved in virus-based systems. Expression of glucocerebrosidase in baculovirus enabled very high levels of expression and to some extent allowed to tell the differences between mutant proteins. ${ }^{2-4}$ Vaccinia virus-driven expression allowed very high levels of expression of the recombinant proteins. Measurements of enzymatic activity in cells loaded with fluorophorlabelled glucosylceramide showed that the degree of residual activity of the mutant glucocerebrosidases correlated well with phenotypes associated with individual mutations. 5

For routine evaluation of mutant alleles an expression using plasmid transfection, which does not require timeconsuming selection and purification of mutant viruses, may prove useful. The aim of this work was to test the capability of plasmid transfection-based expression of glucocerebrosidase to differentiate between deleterious and neutral mutations.

\section{Materials and methods Plasmid construction}

pTM1-glu1 containing wild-type glucocerebrosidase cDNA under control T7 promotor was used as the expression vector. The vector contained both glucocerebrosidase ATG codons. It was shown to achieve higher levels of enzyme expression than vectors containing only one of the ATG codons. $^{6}$

Transformer $^{\mathrm{TM}}$ Site-Directed Mutagenesis Kit (Clontech Laboratories, Inc.) was used, according to the manufacturer's recommendations for the introduction of mutations listed in Table 2, into the vector. The sequences were confirmed by sequencing.

\section{Cells}

HeLa G cells and BSC40 cells were grown in Dulbecco's modified Eagle's medium (DMEM) supplemented with 10\% (v/v) neonatal calf serum (NCS) (Gibco).

Gaucher fibroblasts (L444P/S107L) were grown in DMEM containing $10 \%$ fetal calf serum (FCS). This primary fibroblast cell line was obtained from type 2 Gaucher patient (patient number \#24, Hodanova et $\mathrm{al}^{7}$ ).

Thymidine kinase-deficient 143 cells (143 TK(-)) were grown in DMEM supplemented with $10 \% \mathrm{FCS}$ and $25 \mu \mathrm{l} / \mathrm{ml}$ 5 -bromodeoxyuridine. All cells were grown at $37^{\circ} \mathrm{C}$ in the presence of $5 \% \mathrm{CO}_{2}$ and $95 \%$ humidity.

\section{Viruses}

Wild-type vaccinia virus strain (WR), recombinant vaccinia virus expressing the T7 RNA polymerase (vTF7-3), and recombinant viruses (harbouring normal or mutated glucocerebrosidase cDNAs: v-WT-glu1, v-72delC, v1326insT, and v-S196P) were used.

Recombinant viruses were generated, selected with bromodeoxyuridine, and purified according to standard protocols. $^{8}$

Briefly, four recombinant vaccinia viruses expressing wild-type and mutated glucocerebrosidase cDNAs under the control of $\mathrm{T} 7$ promoter were prepared. Three to five rounds of selection were required to purify the viruses to homogeneity, which was verified by Southern blotting. The sequence of the glucocerebrosidase minigenes was verified by direct sequencing of the viral DNA or sequencing of PCR products where vaccinia genomic DNA served as the template, to exclude the possibility that mutations were introduced into the inserts during selection with bromodeoxyuridine.

\section{Infection}

BSC40 or fibroblast cells $\left(0.2 \times 10^{6}\right)$ were co-infected with vTF7-3 (10 PFU/cell) and individual recombinant viruses (10 PFU/cell) harbouring either normal or mutant glucocerebrosidase. After $1 \mathrm{~h}, \mathrm{FCS}$ or NCS was added to the final concentration of $2 \%(\mathrm{v} / \mathrm{v})$. After $24 \mathrm{~h}$, the cells were collected, washed with PBS and a cell lysate was prepared by three times freezing-thawing and sonication. The crude lysates were used for $\beta$-glucosidase activity measurement and/or Western blotting.

\section{Plasmid transfection}

BSC40 or fibroblast cells $\left(0.2 \times 10^{6}\right)$ were infected with vTF7-3 vaccinia virus (10 PFU/cell) in a serum-free medium. After $1 \mathrm{~h}$, the virus was removed and the cells were transfected with $1.5 \mu \mathrm{g}$ plasmid DNA using $5 \mu \mathrm{l}$ LipofectACE (Gibco). After $4 \mathrm{~h}$, serum (FCS) was added to the final concentration $2 \%$. After $24 \mathrm{~h}$, cell lysates were prepared and samples were assayed.

\section{Enzymatic activity}

$\beta$-glucosidase activity was measured spectrofluorometrically with 4-methylumbelliferyl $\beta$-D-glucopyranoside as a substrate. ${ }^{9}$ Protein concentration was estimated using the 2-bicinchoninic acid protein assay (Pierce Chemical, Antwerp, Belgium).

\section{Western blotting}

Cell lysates containing $10 \mu \mathrm{g}$ of protein were subjected to SDS-PAGE and Western blotting and immunodetection were performed as previously described. ${ }^{10}$

Polyclonal anti-glucocerebrosidase antibody 0126 (a kind gift of Dr Aerts) was used as the primary antibody.

\section{Patients}

Mutations found in a cohort of Czech and Slovak patients were selected for expression studies. The clinical and 
Table 1 The patients

\begin{tabular}{|c|c|c|c|c|c|}
\hline No & Sex & $A g e^{\mathrm{a}}$ & $\begin{array}{l}\text { Genotype } \\
\text { trivial names }\end{array}$ & Phenotype and notes & $\begin{array}{l}\beta \text {-glucosidase activity in } \\
\text { leukocytes }(\mathrm{nmol} / \mathrm{mg} / \mathrm{h})\end{array}$ \\
\hline 3 & $\mathrm{~F}$ & ${ }^{\mathrm{c}} 22$ & N370S/1263del55 & Splenectomy & ND \\
\hline 4 & M & 20 & N370S/1326insT & $\begin{array}{l}\text { MS, mild hepatosplenomegaly, pancytopenia, } \\
\text { enzyme therapy }\end{array}$ & 1.9 \\
\hline 11 & $\mathrm{~F}$ & 11 & N370S/S196P & $\begin{array}{l}\text { MS, moderate splenomegaly, mild hepatomegaly, } \\
\text { thrombocytopenia, enzyme therapy }\end{array}$ & 1.9 \\
\hline 13 & M & ${ }^{c} 50$ & N370S/D409H+T369M & $\begin{array}{l}\text { MS, splenectomy, mild hepatomegaly, severe } \\
\text { cardiopulmonary amyloidosis }(10)\end{array}$ & 2.8 \\
\hline 18 & $\mathrm{~F}$ & 44 & N370S/G202E & $\begin{array}{l}\mathrm{M} \text {, moderate splenomegaly, mild hepatomegaly, } \\
\text { severe thrombocytopenia, enzyme therapy }\end{array}$ & 2.3 \\
\hline 27 & $\mathrm{~F}$ & 9 & N370S/L444P+V460V & $\begin{array}{l}\text { MS, mild splenomegaly, leukopenia, mild } \\
\text { thrombocytopenia }\end{array}$ & 2.3 \\
\hline
\end{tabular}

Note: ND, not done.

Patient carrying mutation 72 delC was reported by Beutler et al. ${ }^{11}$

${ }^{\text {aAge }}$ at evaluation.

bNucleotides numbered from the first ATG. ${ }^{18,19}$

${ }^{\mathrm{c}}$ Age at death, $\mathrm{M}$, mild phenotype, MS, moderately severe phenotype.

laboratory features of the patients are summarised in Table 1 and by Hodanova et al. ${ }^{7}$ The numbering of patients is identical to the previous study. ${ }^{7}$

The previously described mutant allele 72delC, which produces a shift of reading frame and a stop 51 amino acids downstream the normal protein cleavage site, was also included. ${ }^{11}$

The previously characterised common mutations, N370S and $\mathrm{L} 444 \mathrm{P}^{5}$, were re-expressed for comparison.

\section{Results}

Site-directed mutagenesis

Expression vectors carrying mutations: 72delC, 1326insT, 1263del55, S196P, N370S, L444P, G202E, D409H, T369M, $\mathrm{L} 444 \mathrm{P}+\mathrm{V} 460 \mathrm{~V}$ and $\mathrm{D} 409 \mathrm{H}+\mathrm{T} 369 \mathrm{M}$ were prepared by sitedirected mutagenesis. The inserted part of the vector was sequenced to verify that only the desired mutation was present in the cDNA minigene.

\section{Expression of wild-type and mutant glucocere- brosidases}

Expression of glucocerebrosidase by recombinant vaccinia viruses yielded very high levels of $\beta$-glucosidase activity. The average expressed activity of wild-type glucocerebrosidase in BSC40 cell line was $1200( \pm 600) \mathrm{nmol} / \mathrm{mg} / \mathrm{h}$. The average endogenous $\beta$-glucosidase activity of these cells constituted about $3 \%$ of the above activity. All mutant glucocerebrosidase forms had activity lower than $5 \%$ of the expressed wild-type. The activity of glucocerebrosidase carrying the missense mutation S196P was more than twice higher than that presented by other tested mutations (See Table 2).

The L444P/S107L fibroblast cell line had no measurable endogenous $\beta$-glucosidase activity ( $<1 \%$ of $\beta$-glucosidase activity of control fibroblasts).
Table 2 The glucocerebrosidase activity of wild-type and mutant glucocerebrosidases expressed by recombinant vaccinia viruses and from plasmids

\begin{tabular}{lccc}
\hline & $\begin{array}{c}\text { Recombinant virus } \\
\text { BSC40 } \\
(\mathrm{n}=4)\end{array}$ & $\begin{array}{c}\text { Fibroblasts } \\
(\mathrm{n}=1)\end{array}$ & $\begin{array}{c}\text { Plasmid expression } \\
\text { Fibroblasts } \\
(\mathrm{n}=5)\end{array}$ \\
\hline WT-glu1 & 100.00 & 100 & 100.00 \\
72delC & $0.68 \pm 0.98$ & 0 & $1.73 \pm 2.22$ \\
1326insT & $1.50 \pm 1.07$ & 0 & $0.80 \pm 0.50$ \\
S196P & $5.07 \pm 0.49$ & 2 & $7.51 \pm 5.85$ \\
N370S & ND & ND & $9.31 \pm 4.33$ \\
L444P & ND & ND & $5.42 \pm 1.73$ \\
G202E & ND & ND & $3.03 \pm 1.66$ \\
D409H & ND & ND & $5.47 \pm 2.56$ \\
T369M & ND & ND & $40.41 \pm 13.68$ \\
L444P+V460V & ND & ND & $5.24 \pm 2.32$ \\
D409H+T369M & ND & ND & $1.21 \pm 0.17$ \\
1263del55 & ND & ND & $0.70 \pm 1.99$ \\
\end{tabular}

The values of glucocerebrosidase activities are presented as mean \pm SEM percentage of the activity obtained for expressed wild-type glucocerebrosidase.

$\mathrm{n}$, number of experiments; ND, not done.

We have also attempted to use HeLa G cells, but the endogenous activity of the cells infected with vTF7-3 virus accounted for more than $70 \%$ of total $\beta$-glucosidase activity of expressed wild-type human glucocerebrosidase (data not shown).

In all, 11 mutant and wild-type glucocerebrosidase forms were expressed from plasmids in the Gaucher fibroblast cell line. The expressed glucocerebrosidase proteins carried missense mutations (S196P, N370S, L444P, G202E, D409H, T369M), null mutations-insertion, deletions (72delC, 1326insT, 1263del55), and complex mutations (L444P+V460V, D409H+T369M). The mutations S196P, G202E, 1326insT, and complex mutations (L444P+V460V, 

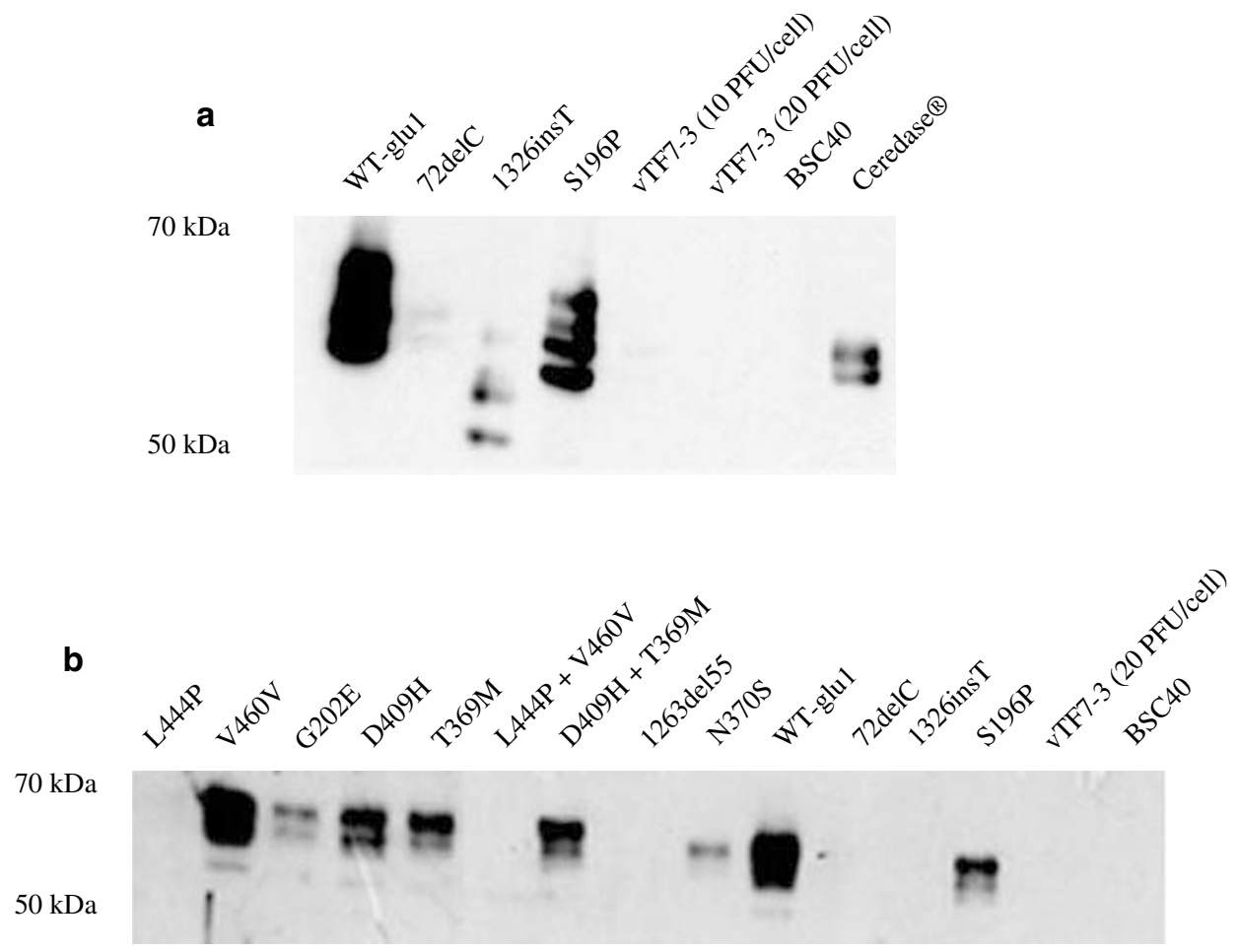

Figure 1 Western blotting of the wild-type and mutant glucocerebrosidases expressed in BSC40 by: (a) Recombinant viruses. $1 \mu$ l of $100 \times$ diluted Ceredase ${ }^{\circledR}(80 \mathrm{U} / \mathrm{ml})$ was included as a Mr standard (Lane 8$)$. (b) Plasmid expression. Crude lysates containing $10 \mu \mathrm{g}$ of protein were analysed by SDS-PAGE (10\%), followed by immunoblotting using a polyclonal anti-glucocerebrosidase antibody 0126.

D409H+T369M) were found in Czech Gaucher patients. Mutations 1263del55 and T369M are uncommon mutations detected in unrelated families. ${ }^{11,12}$

Plasmid expression of wild-type glucocerebrosidase yielded significantly lower levels (less than 16\%) of expression compared to that achieved by expression driven by recombinant virus. The average activity of wild-type glucocerebrosidase was $105( \pm 60) \mathrm{nmol} / \mathrm{mg} / \mathrm{h}$ in BSC40 and $207( \pm 90) \mathrm{nmol} / \mathrm{mg} / \mathrm{h}$ in fibroblasts. The activities of mutant glucocerebrosidases were $10 \%$ of the normal activity, with the exception of T369M, whose activity reached $40 \%$ of wild-type glucocerebrosidase. Activity of all mutant glucocerebrosidase forms was significantly reduced, although it was not possible to distinguish reliably the severity of mutations.

The amount of protein directed by the different mutated alleles was tested by Western blotting. The expressed wildtype human $\beta$-glucocerebrosidase strongly reacted with the polyclonal anti-human $\beta$-glucocerebrosidase antibody and produced a multiple-band pattern that corresponds to differentially glycosylated forms of the enzyme. The same pattern was observed for mutant glucocerebrosidase forms (see Figures $1 \mathrm{a}$ and $\mathrm{b}$ ).

When expressed from recombinant virus no immunoreactive protein was detected in the null mutation $72 \mathrm{delC}$, while the amount of immunoreactive protein in mutation S196P was comparable to that of wild-type glucocebrosidase. A reduced amount of immunoreactive protein with a molecular weight lower than that of the wild-type glucocerebrosidase was detected in mutation 1326insT.

A reduced amount of immunoreactive protein was detected in cells transfected with plasmids carrying the missense mutations: G202E, D409H, T369M, N370S, S196P, and D409H+T369M. No protein was detected in the alleles carrying the mutations: L444P, complex (L444P+V460V), and several null mutations (72delC, 1326insT, and 1236del55).

\section{Discussion}

Glycosylation is necessary for catalytic activity of glucocerebrosidase. The expression in eukaryotic expression systems is thus mandatory for the functional studies of mutant glucocerebrosidase. Baculovirus-based system was used for the expression of mutant glucocerebrosidases and to some extent allowed to differentiate between activities of individual mutant enzymes. ${ }^{1,2,4}$ The advantage of the vaccinia-based expression system lies in the use of human cell lines. In addition, vaccinia virus shuts off the host 
protein synthesis, ${ }^{13}$ thus significantly depressing residual endogenous $\beta$-glucosidase activity.

The endogenous activity of the cell line used for expression may present a serious obstacle in the evaluation of the low residual activity of mutant glucocerebrosidase forms. We used three cell lines (HeLa G, BSC40, and Gaucher fibroblasts L444P/S107L). The endogenous $\beta$-glucosidase activity of the HeLa G cell line was very high (70\%), therefore it could not be used for transient expression.

The endogenous activity of BSC40 cells constituted about $25 \%$ of the total $\beta$-glucosidase activity of the transiently expressed wild-type glucocerebrosidase and therefore the cells were efficient for infection experiments. Gaucher fibroblasts L444P/S107L had no detectable $\beta$-glucosidase activity (less than $0.1 \%$ of controls) and were suitable even for expression using plasmids.

The pathogenicity of five novel mutations found in Czech Gaucher patients has been verified and the deleterious effect on catalytic activity of six known mutations was confirmed.

The glucocerebrosidase forms carrying null mutations (72delC, 1326insT, and 1263del55) had lower $\beta$-glucosidase activity (average activity was less than $2 \%$ of wild-type glucocerebrosidase activity) than the missense mutations (S196P, N370S, L444P, G202E, and D409H) where average activity was $3-10 \%$ of that of the wild-type.

Residual activity significantly higher than that presented by the mild N370S mutation was observed for the T369M ( 9.3 and $40.4 \%$ of wild-type glucocerebrosidase activity, respectively). This may suggest that the $\mathrm{T} 369 \mathrm{M}$ is a very mild mutation, even on the verge of polymorphism. This statement is also supported by the mild phenotype of two siblings who are compound heterozygotes for mutations N370S and T369M. ${ }^{12}$ However, the activity of the mutant protein with the natural substrate was not studied.

The S196P produced high steady-state levels of mutant protein with severely reduced enzyme activity. According to classification proposed by Beutler and Gelbart, ${ }^{14}$ the S196P is apparently a severe mutation, as it was found in homozygosity in a type 2 patient. ${ }^{15}$ This corresponds well with the moderate to severe phenotype observed in patient 11, who carries mutations N370S and S196P.

Undetectable amount of immunoreactive protein was found in frameshifts and also in missense mutation L444P when expressed from plasmid. The L444P is known to produce active, but unstable protein. ${ }^{16}$ Notable steadystate amounts of L444P mutant protein were found by Pasmanik-Chor et al. ${ }^{5}$ using vaccinia virus expression system, which produces significantly higher amounts of recombinant protein. The amount of the unstable L444P glucocerebrosidase expressed using plasmid transfection may be below the detection limit of Western blotting. Indeed, when glucocerebrosidase with frameshift 1326insT was expressed from recombinant vaccinia virus, a low amount of immunoreactive glucocerebrosidase with lower molecular weight was detected by Western blotting. No immunoreactive material, however, was detected when the same mutant protein was expressed from plasmid.

In plasmid transfection the level of expression depends largely on the efficiency of the transfection, which may vary in each experiment. In spite of that the pathogenic mutations could be clearly distinguished from polymorphisms. Transient vaccinia virus-driven expression of glucocerebrosidase in deficient human cell lines thus enables reliable differentiation of deleterious and neutral mutations.

While the expression of mutant glucocerebrosidase determines a residual activity of the enzyme and possibly also the severity of the mutation, the prediction of the phenotype on the basis of genotype remains imprecise. This suggests that there are other genetic and enviromental factors which modulate the phenotype of Gaucher patients. Also, owing to presumably dimeric structure of native glucocerebrosidase ${ }^{17}$, it cannot be excluded that different mutant glucocerebrosidases influence each other in compound heterozygotes.

\section{Acknowledgements}

This work was supported by a grant from Charles University (GA UK 6-131/ 96) and Ministry of Education, Czech Republic (VZ 111100003).

\section{References}

1 Beutler E: Gaucher disease. Adv Genet 1995; 32: 17-49.

2 Grabowski G, White WR, Grace ME: Expression of functional human acid beta-glucosidase in COS-1 and Spodoptera frugiperda cells. Enzyme 1989; 41: 131-142.

3 Grace ME, Desnick RJ, Pastores GM: Identification and expression of acid beta-glucosidase mutations causing severe type 1 and neurologic type 2 Gaucher disease in non-Jewish patients. J Clin Invest 1997; 99: 2530-2537.

4 Amaral O, Marcao A, Sá Miranda MC, Desnick RJ, Grace ME: Gaucher disease: expression and characterization of mild and severe acid beta-glucosidase mutations in Portuguese type 1 patients. Eur J Hum Genet 2000; 8: 95-102.

5 Pasmanik-Chor M, Madar-Shapiro L, Elroy-Stein O, Aerts J, Gatt S, Horowitz M: Expression of mutated glucocerebrosidase alleles in human cells. Hum Mol Genet 1997; 6: 887-895.

6 Pasmanik-Chor M, Elroy-Stein O, Aerts J, Agmont V, Gatt S, Horowitz M: Overexpression of human glucocerebrosidase containing different-sized leaders. Biochem J 1996; 317: 81-88.

7 Hodanova K, Hrebicek M, Cervenkova M, Mrazova L, Veprekova L, Zeman J: Analysis of the $\beta$-glucocerebrosidase gene in Czech and Slovak Gaucher patients: mutation profile and description of six novel mutant alleles. Blood Cells Mol Dis 1999; 25: 287-298.

8 Ausubel FM, Brent R, Kingston RE et al: Short protocols in molecular biology, 2nd edn. New York: J Wiley, 1992.

9 Wenger DA, Williams C: Screening for lysosomal disorders; in Hommes FA, (ed). Techniques in diagnostic human biochemical genetics. New York: Wiley-Liss, Inc., 1991 pp 587-617.

10 Hrebicek M, Zeman J, Musilova J et al: A case of type I Gaucher disease with cardiopulmonary amyloidosis and chitotriosidase deficiency. Virchows Arch 1996; 429: 305-309. 
11 Beutler E, Gelbart T, West C: Identification of six new Gaucher disease mutations. Genomics 1993; 15: 203-205.

12 Beutler E, Gelbart T, Balicki D: Gaucher disease: four families with previously undescribed mutations. Proc Assoc Am Physicians 1996; 108: 179-184.

13 Moss B, Ahn BY, Amegadzie B, Gershon PD, Keck JG: Cytoplasmic transcription system encoded by vaccinia virus. J Biol Chem 1991; 266: $1355-1358$

14 Beutler E, Gelbart T. Hematologically important mutations: Gaucher disease. Blood Cells Mol Dis 1998; 24: 2-8.

15 Stone DL, Tayebi N, Orvisky E, Stubblefield B, Madike V, Sidransky E: Glucocerebrosidase gene mutations in patients with type 2 Gaucher disease. Hum Mutat 2000; 15: 181-188.
16 Grace M, Berg A, He GS, Goldberg L, Horowitz M, Grabowski GA: Gaucher disease: heterologous expression of two alleles associated with neuronopathic phenotypes. Am J Hum Genet 1991; 49: 646-655.

17 Choy FY, Woo M, Potier M: In situ radiation-inactivation size of fibroblast membrane-bound acid beta-glucosidase in Gaucher type 1, type 2 and type 3 disease. Biochim Biophys Acta 1986; 870: 76-81.

18 Sorge J, West C, Westwood B, Beutler E: Molecular cloning and nucleotide sequence of human glucocerebrosidase cDNA. Proc Natl Acad Sci USA 1985; 82: 7289-7293.

19 Horowitz M, Wilder S, Horowitz Z, Reiner O, Gelbart T, Beutler E: The human glucocerebrosidase gene and pseudogene: structure and evolution. Genomics 1989; 4: 87-96. 